\title{
Human rights: The convergence of the second sila of Pancasila and Hans Kung's global ethics in Indonesia
}

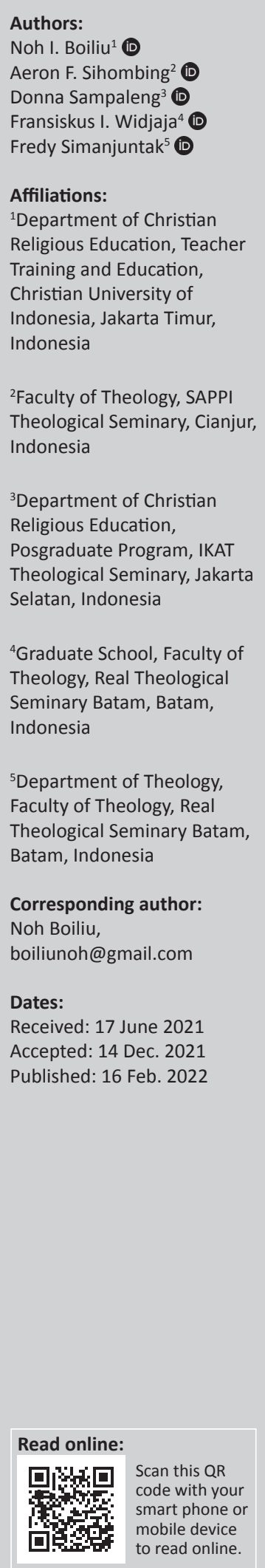

The objective of this research is to find the meeting point between the second precept of Pancasila and the global ethics of Kung. The article also discusses the value of the second precept of Pancasila as found in the global ethics. This research is intended to recognise human rights as the convergence of the second sila (principle) of Pancasila, namely, 'a just and civilised humanity' with Hans Kung's global ethics. The method used in this research is a literature study containing relevant theories. The second principle of Pancasila, Kemanusiaan yang Adil dan Beradab, is the basis for understanding the life of humanity, unity and justice in Indonesia and becomes the basis for humans to understand themselves and others.

Contribution: This research offers significant insights into the value of human rights as a meeting point between the second sila of Pancasila and Hans Kung's global ethics. The second sila of Pancasila and Hans Kung's global ethics emphasise that everyone has rights. Human rights do not contradict with the typical Indonesian culture of deliberation and mutual cooperation, because the second principle of Pancasila, namely, a just and civilised humanity, is the basis for ensuring human rights. The Constitution of Indonesia of 1945, article 27 paragraph 1 also guarantees human rights. Human rights do not encourage individualism; instead, they protect individuals and groups. Human rights are not meant to promote egoism, but they help to maintain solidarity among people and ensure the well-being of society. They are a means to respect human dignity and protect the weak.

Keywords: human rights; second sila; Pancasila; Hans Kung; global ethics.

\section{Introduction}

The objective of this research is to determine the similarities between the second precept of Pancasila and the global ethics of Hans Kung. It also aims to recognise the inherent values of Pancasila in global ethics. Both the second sila of Pancasila and the global ethics of Hans Kung consider concepts such as human values, human rights and equality of all human beings. Eka Dharmaputra states that Pancasila is the identity of Indonesia (Vernooij 2015:201-203). Moreover, it must be the legal basis for Indonesia (Suseno 2013:138-142). It is not surprising that John Titaley explicitly stated that Pancasila is God's gift for the Indonesian people (Titaley 2013). Therefore, Pancasila converges with Kung's global ethics that inherently has universal values.

Meo (2019:103-122) has researched Kung's global ethics related to dialogues among the different religious groups in Indonesia. Indonesia is a pluralistic nation with various religions. Therefore, the convergence point between Pancasila and Kung's global ethics includes topics like humanity, justice and peace. In his research, Meo relates Kung's global ethics to the third sila of Pancasila, namely, 'unity in diversity' (Meo 2019). Meo merely discusses Kung's global ethics from the perspective of the third sila of Pancasila. This study is the first attempt to examine and compare the relationships between Kung's global ethics and the second sila of Pancasila.

Similar research conducted by Latuheru, Lattu and Tampake (2020:150) on the contribution of Kung's global ethics uses Pancasila as a common ground for interfaith dialogue in Indonesia. Using Gadamer's hermeneutics, they try to determine how Pancasila has sustained the nation's life throughout the history of Indonesia (Latuheru et al. 2020). This distinguishes their research from that of Meo.

Meanwhile, Widjaja (2020:143-168) researched that Pancasila is a minimalist morality originating from Indonesian society itself, which has the resonance of the virtues of

How to cite this article: Boiliu, N.I., Sihombing, A.F., Sampaleng, D., Widjaja, F.I. \& Simanjuntak, F., 2022, 'Human rights: The convergence of the second sila of Pancasila and Hans Kung's global ethics in Indonesia', HTS Teologiese Studies/Theological Studies 78(4), a6933. https://doi.org/10.4102/hts.v78i4.6933

Copyright: ๑ 2022. The Authors. Licensee: AOSIS. This work is licensed under the Creative Commons Attribution License. 
Christianity. Therefore, the values of Pancasila must be put into practice in the lives of Indonesian people, including their religious life (Widjaja 2020:143-168). Widjaja states that Christianity inherently has the values of the Pancasila. Thus, Widjaja's approach is to draw special attention to the noble virtues of the Indonesian nation, namely Pancasila, and associate them with the universal religious values.

Franz Magnis Suseno is different from Widjaja in that Pancasila is the ethical basis that unites the Indonesian nation (Suseno 2013). Pancasila provides a necessary condition for witnessing Christian faith in the form of theological discourse. In other words, Pancasila guarantees freedom of worship for Christians. Yet, Iskandar (2016:723-735) has a different view about Pancasila. He views Pancasila as a delusion or superstition because of the contradiction between liberalism and communism and the challenges from radical religion. Even though Iskandar's approach is political, the warning is essential to defend and fight for Pancasila. This article proposes that Christian theology, especially Hans Kung's theology of global ethics, is not contradictory with the second sila of Pancasila.

\section{Method}

The method used in this research is a literature study involving relevant theories. Firstly, the article explains the second sila of Pancasila. Secondly, a description of the global ethics of Hans Kung is given. Thirdly, a comparative study of these two main ideas is presented. This step is carried out to recognise the convergence of the second sila of Pancasila and Hans Kung's global ethics in Indonesia. This helps to advocate universal human values.

\section{Discussion}

\section{The second sila of Pancasila: Just and civilised humanity}

Driyarkara asserts that 'Indonesia is neither a religious nor a secular state, but a Pancasila state' (Wibowo 2018:115). As a Pancasila state, 'a governmental system separates religion from the state while maintaining a religious dimension' (Wibowo 2018). Accordingly, the state is not superior to religion. Also, religion is not superior to the state. Driyarkara's interpretation of Pancasila is based on his humanitarian philosophy (Wibowo 2018). Therefore, words such as 'majority' and 'minority' are irrelevant to Indonesia, even though Islam is the major religion. Thus, Indonesia is a state that is both secular and religious. In Pancasila state, subordination and total separation are also rejected. This rejection is apparent in Indonesia. The consensus is, (1) that the Pancasila state is neither a secular state (hence, the idea of a total separation is rejected) nor a religious state (hence, the idea of a total subordination is also rejected); (2) that in the Pancasila state there is neither a religious state (subordination of the State to religion) nor a state religion (subordination of religion to the State) (Dirjen Bimas Kristen Protestan 1997:92).
Pancasila is the foundational concept for the existence of a civilised humanity in Indonesia (Tanamal \& Siagian 2020: 35-48). It is specified in the preamble of the 1945 Constitution of Indonesia. Article 1 of the constitution states, 'The State is based on the One Almighty God'. Article 2 says, 'The State guarantees the freedom of each citizen to embrace their respective religions, and to worship according to their respective religions and beliefs'.

Human rights are standards that protect the dignity of all human beings and enable them to maintain harmony in society (Syarbaini 2011:264). These are 'basic rights inherent in human beings, which is universal and as a gift of God' (Siahaan 1994:82). They do not stand on their own, but they are necessarily related to the legitimate rights of others and the obligation to be respectful of others (Darmaputera 1994:71).

The characteristics of human rights are as follows: (1) Human rights are understood in terms of human relations with others. These rights help to maintain proper relationships among the people in a community or society. (2) Human rights acknowledge the existence of obligations and responsibilities of all human beings. Rights and duties are inseparable; humans can have rights when they have fulfilled their obligations. (3) All human rights can be summed up as follows: there is only one human right, namely, the right of every person to be treated as humans, which are worthy of honour or respect. The constitutional laws of a state preserve human rights and also stipulate the obligations of every citizen (Hasibuan 1994:47).

Human rights are guaranteed and protected by the Constitution of Indonesia, which elaborates the second sila of Pancasila. This is revealed in Article 1 paragraph (1) No.39/1999 on Human Rights, which states that the government, and every citizen are obliged to respect, uphold and protect human rights (Syarbaini 2011:264). Article 27 paragraph 1 of the 1945 Constitution states that all citizens are equal before the law and government and says that they are obliged to obey the laws of the government without exception.

The National Defense Council says the following about human rights: Humans are God's creation, for Indonesian people are humans created by God Almighty; Pancasila is the principle in the life of Indonesian society and the 1945 Constitution is the foundation of the Republic of Indonesia as an independent and sovereign state, intending to endeavor a sense of security and serenity, welfare, prosperity, intelligence and social justice for all Indonesian people (Kawulusan 1994:64). Hasibuan (1994:65) considers it as the continuation of the right to freedom. It is the basis for people in obtaining legal justice and protection from persecution and ill treatment by others (Hasibuan 1994:65).

In the Indonesian context, human rights can be classified as follows: (1) human rights related to God Almighty; that is, every human being has the right to embrace his or her own religion or belief and to determine how to worship God; (2) human rights that are involved in the relationships among 
fellow human beings. Every human being has the right to freedom. Thus, all forms of colonialism and exploitation that degrade human dignity must be eliminated. Every human being has the right to receive the same treatment as an independent and dignified individual, regardless of gender, ethnicity, nationality, race, religion, political views and social status and (3) human rights that are involved in the relationships of every citizen towards the state; every human being in the nation has the right to freedom. Each person in the nation has the right to obtain peace and justice, which are the foundation of the nation's social relations. Every human being in the nation is entitled to receive protection from coercion by other countries and has the right to obtain political asylum (Siahaan 1994:83).

Unity in Indonesian diversity is one of the noble universal values that can converge global ethics based on biblical ethics (Boiliu 2017:199-209). Darmaputera (1994:51-54) states that Indonesian unity is the proper condition where Pancasila can function well, and it enables Indonesian people to live together as a nation. This unity can be made possible only if the second sila of Pancasila has been implemented. The second sila is necessarily an ethical normative framework concerning what ought to be done and what ought not to do to others. It is wrong to dehumanise other human beings. Wibowo's interpretation of Driyarkara on Pancasila is of Pancasila in its relation to Religion and State, which means that the State exists to achieve horizontal prosperity (Wibowo 2018:137).

This is the basis for honouring and respecting diversity in the Indonesian state and to avoid any discrimination based on ethnicity, race or religion in the society. On the other hand, this principle allows for the existence of different cultures, languages, ethnicities, religions and beliefs in the nation. But, all these differences are not regarded as obstacles to the unity of the nation. The motto Bhineka Tunggal Ika means the unity in diversity of Indonesia that serves to prevent any antihumanitarian activities in the nation because there is an inherent respect for plurality in it.

\section{Hans Kung's global ethics}

Kung (Kung \& Schmidt 1998:51-54) comments that global ethical values are contained in the religions and beliefs of this world. All pure and true religions reflect humanity. It is the characteristic of true religion. The foundation of global ethics of humanity is God himself and not human autonomy that is rooted in human rationalism. It is also not based on the ignorance of God as the atheists have done. Humans are indeed rational beings, but:

$[H]$ e cannot avoid his dependence on God, because God is the necessary foundation of human life. This is the basis of humanity. Kung calls it man's THEONOMY. It is the basis for human's belief, about identity, meaning, ultimate values, priorities and his life's reference point are rooted and derived from God himself. (Kung 1976:534)

Global ethics not only deals with equality but also plurality. This means eliminating all forms of discrimination based on ethnicity, race, religion, nationality, culture, social status and also the distinctions between developed and non-developed countries. It also includes eliminating anti-Semitism in the church and all the religions in the world (Kung \& Schmidt 1998:65-69).

\section{Kung said that:}

[A] global ethic must uphold not only independence but also justice. It requires a social world order, human equality; no discrimination between rich and poor, providing employment, fighting for human rights and also releasing oppressed people, conducting a life that is governed by world ethics and norms, helping the poor and hungry. (Kung \& Schmidt 1998:67)

Justice is not all about human welfare, it is also about 'solidarity towards the environment. Humans should not only exploit nature but must live harmoniously with and protect it. Therefore, humans must be friendly with the natural environment' (Kung \& Schmidt 1998:68).

Kung's global ethics also advocates for the promotion of human rights in the following ways: faith, love, sympathy, self-denial, and the power of thought and truth within are the greatest strengths rather than hatred, enmity and selfishness. A sense of duty-bound commitment to support and defend the poor and fight their oppressors and high hopes for the victory of goodness (Kung 1988:243).

The statements mentioned above are similar to Kung's remarks in his book Global Ethics and Global Responsibilities, 'in global ethics, it is not only a matter of brotherhood mainly but also sisterhood, where there is no longer a distinction between men and women in the church' (Kung \& Schmidt 1998:68).

\section{The convergence point of the second sila of Pancasila and Hans Kung's global ethics}

The principle of a just and civilised humanity is the essence of the convergence of Pancasila and Hans Kung's global ethics. It is an essential value in Pancasila (Suseno 2013:138142) because humans are God's creations as stated by the first sila of Pancasila. Therefore, Pancasila dignifies the Indonesian people as human beings, who deserve justice and recommends for a civilised humanity. Pancasila upholds and defends the human rights of Indonesian people who are different in their religions, cultures, languages, customs, social and economic status.

The noble values contained in the five silas of Pancasila are universal, which derive from the cultural values and beliefs of the Indonesian people. The five silas of Pancasila strive to fight for a civilised humanity. It is the core ideology and the basis of all ethical principles of the country.

Hans Kung's global ethics embraces others because others are considered as brothers despite the existing differences. This requires tolerance on the part of all people, so that brotherhood and mutual understanding can be established in society. The concept of Pancasila and especially Bhinneka Tunggal Ika, the national motto of Indonesia, also call for tolerance and 
brotherhood towards others. The idea underlying these concepts is that one should avoid hurting others. In other words, treat others in a way that you would like to be treated. Respect others and help those who are in need. Differences in ethnicity, religion, culture and social status should not be a barrier in providing assistance to others.

Hans Kung's global ethics is not a teaching or theology that is absolutely true. It is because absolute truth belongs only to God, while all existing theological systems or religious teachings partly possess the truth (not the whole truth). Therefore, every human being must honour and respect the teachings, views and doctrines embraced by others. The second principle of Pancasila is still relevant and dynamic in order to face changing times because it, as well as the other four principles, guarantee rights, freedom, and democracy. Thus, plurality is a necessity for both Hans Kung's global ethics and Pancasila, so that diversity in cultures, beliefs, religions, ethnicities, social status and languages can be accepted, respected and honoured. So, the people of Indonesia must uphold and maintain the plurality of the nation, because it is an indispensable feature of the country.

One of the most critical values in Hans Kung's global ethics is self-criticism, which means to evaluate oneself or one's actions. The ideology, belief, religion or knowledge of every person contain some weaknesses that Kung calls a black stain. Every individual and religious community should be aware of their own limitations and shortcomings. Thus, nobody can claim to possess the absolute truth. Every person must stand up with courage to condemn the evil acts, whether they are done by the government, religion, group of people, political party or any others. Any act that dehumanises other people must be denounced. Jesus taught his people to say yes for yes and no for no. All humans must have the courage to state the truth, even though there is a possibility of a high risk of suffering because of it.

The second sila of Pancasila and Hans Kung's global ethics provide equal status for men and women, acknowledge women's talents and abilities and recognise women's role in church ministry. Thus, women are equal with men, so discrimination against women should be eliminated and they should be considered partners (sisters). If brotherhood is built on a pluralistic society, then peace will be achieved in the world, including Indonesia.

The second precept of Pancasila and the global ethics calls for respect for the views of each individual and group. Any individual or group should not think that they are the only right one, instead they must try to understand and respect each other. It aims to uphold social justice for all human beings of various backgrounds, especially those who are marginalised, poor or powerless to protect themselves such as orphans and widows.

There are the universal values in the second sila of Pancasila and Hans Kung's global ethics because humanitarian values, such as equality of rights and freedom of speech, are universally accepted by all religions and beliefs. It is similar to biblical ethics, which raise voice to defend the human rights of the oppressed. It is the convergence between Pancasila, global ethics and biblical ethics. Thus, a common feature (Moltman 1988:39) of Pancasila and global ethics is that both these concepts call for a just and civilised humanity. Pancasila, which is the foundation of the Indonesian nation, recognises a pluralistic world order. Similarly, global ethics seeks to accept and appreciate the differences in all human beings.

In the present context, this convergence point provides fresh air for each group, race, and religion in terms of 'legal standing equality in public life as fellow citizens' (Sudarminta 2018:164). Meaning, it can suppress 'the threat of harmony in living together in a country ... even for world peace' (Sudarminta 2018:164). This convergence point is seen as an effort to establish ethical and moral values and as a form of constructive social contribution (religion, group, etc.) in the public life of a pluralistic society. It is also an initiative to create a harmonious life for all citizens, by avoiding any selfish attitudes and solving every social problem that adversely affects the unity in society (Sudarminta 2018:165). It means, 'establishing a democratic Indonesian state based on Pancasila, as well as human rights in our constitution' (Suseno 2018:177).

\section{Conclusion}

Pancasila is the foundational concept of the Republic of Indonesia and the basic guiding principle in the life of the Indonesian people. It is an ideal and noble concept. The similarities between Pancasila and Hans Kung's global ethics is that both these concepts insist for the realisation of a just and civilised humanity. Therefore, the second precept of Pancasila and global ethics emphasise that human values must be strengthened and upheld in the life of the people of Indonesia. Pancasila's values are realised and inherent in global ethics. Thus, it makes Pancasila a global ideology and a part of universal noble values, so it must be reinforced in Indonesia.

The central focus of Pancasila and Hans Kung's global ethics are on human beings, especially the need to defend human rights in Indonesia. Both Pancasila and global ethics have universal noble values that are important for all the people in the world, including Indonesia.

\section{Acknowledgements}

The authors thank Prof. Dr Justinus Sudarminta, Society of Jesus, lecturer in Ethics at Driyarkara School of Philosophy, Jakarta, for providing critical notes to develop this article.

\section{Competing interests}

The authors declare that they have no financial or personal relationships that may have inappropriately influenced them in writing this article. 


\section{Authors' contributions}

N.I.B. and A.F.S. developed the concept, wrote the original draft and wrote the script. D.S., F.I.W. and F.S. read the entire manuscript for notes and input. Finally, all authors jointly read and revised the reviews from the reviewers.

\section{Ethical considerations}

This article followed all ethical standards for research without direct contact with human or animal subjects.

\section{Funding information}

This research received no specific grant from any funding agency in the public, commercial or not-for-profit sectors.

\section{Data availability}

Data sharing is not applicable to this article as no new data were created or analysed in this study.

\section{Disclaimer}

The views and opinions expressed in this article are those of the authors and do not necessarily reflect the official policy or position of any affiliated agency of the authors.

\section{References}

Boiliu, N.I., 2011, 'Manusia dan Pluralitas Keyakinan di Indonesia', Jurnal Teologi Stulos 10(1), 53-71.

Boiliu, N.I., 2017, 'Etika Teologi Politik: Analisis Etis Teologis Ketaatan kepada Pemerintah', Revitalisasi Indonesia Melalui Identitas Kemajemukan Berdasarkan Pancasila 8(9), 199-209.

Darmaputera, E., 1994, 'Hak Asasi Manusia Perspektif Teologis Kristiani', in W. Sairin \& J. Pattiasina (eds.), Hubungan Negara dan Hak-Hak Asasi Manusia, pp. 68-76, BPK, Gunung Mulia.
Dirjen Bimas Kristen Protestan, 1997, Bingkai Teologi: Kerukunan Hidup Umat Beragama Menurut Pandangan (Kristen Protestan), Departemen Agama RI, Jakarta.

Hasibuan, A., 1994, 'Hak-hak Asasi Manusia ditinjau dari Aspek Politik', in W. Sairin \& J. Pattiasina (eds.), Hubungan Negara dan Hak-Hak Asasi Manusia, pp. 45-58, BPK, Gunung Mulia.

Iskandar, P., 2016, 'The Pancasila Delusion', Journal of Contemporary Asia 46(4), 723-735. https://doi.org/10.1080/00472336.2016.1195430

Kawulusan, H.E., 1994, 'Hak Asas Manusia dari Sudut Pandang Bangsa Indonesia', in W. Sairin \& J. Pattiasina (eds.), Hubungan Negara dan Hak-Hak Asasi Manusia, pp. 60-67, BPK, Gunung Mulia.

Kung, H., 1976, On being a Christian, Doubleday \& Company, New York, NY.

Kung, H., 1988, Theology for the third millenium an ecumenical view, Doubleday, New York, NY.

Kung, H. \& Schmidt, H., 1998, A global ethics and global responsibilities: Two declarations, SCM Press, London.

Latuheru, A.C., Lattu, I.Y.M. \& Tampake, T.R., 2020, 'Pancasila Sebagai Teks Dialog Lintas Agama dalam Perspektif Hans-Georg Gadamer dan Hans Kung', Jurnal Filsafat 30(2), 150. https://doi.org/10.22146/jf.49193

Meo, R.L., 2019, 'Sumbangan Etika global Hans Küng Demi Terwujudnya Perdamaian Dan Relevansinya Bagi Indonesia', Jurnal Ledalero 18(1), 103. https://doi. org/10.31385/jl.v18i1.157.103-122

Moltman, J., 1988, Theology today, SCM Press, London.

Siahaan, M., 1994, 'Diskusi Hak Asasi Manusia Pusat Pengkajian Hukum Persekutuan Gereja-Gereja di Indonesia', in W. Sairin \& J. Pattiasina (eds.), pp. 77-84, Hubungan Negara dan Hak-Hak Asasi Manusia, BPK, Gunung Mulia.

Sudarminta, J., 2018, 'Agama, Ruang Publik, dan Tantangan Era Pasca-Kebenaran', in F.W. Setyadi (ed.), Meluhurkan Kemanusiaan: Kumpulan Esai untuk A. Sudiarja, pp. 157-169, Penerbit Buku, Kompas.

Suseno, F.M., 2013, 'M. Sastrapratedja, Lima Gagasan Yang Dapat Mengubah Indonesia', Jurnal Diskursus 13(1), 138-142. https://doi.org/10.36383/diskursus.v13i1.98

Suseno, F.M., 2018, 'Toleransi dan Budi Luhur', in F.W. Setyadi (ed.), Meluhurkan Kemanusiaan: Kumpulan Esai untuk A. Sudiarja, pp. 171-182, Penerbit Buku, Kompas.

Syarbaini, S., 2011, Pendidikan Pancasila: Implementasi Nilai-Nilai Karakter Bangsa di Perguruan Tinggi Bogor, Ghalia.

Tanamal, N.A. \& Siagian, S.B.U., 2020, 'Pancasila Sebagai Landasan Visional bagi Spiritualitas Kehidupan Bangsa Indonesia dalam Menangani Intoleransi', Integritas: Jurnal Teologi 2(1), 35-48. https://doi.org/10.47628/ijt.v2i1.22

Titaley, J.A., 2013, Religiositas di Alinea Tiga: Pluralisme, Nasionalisme dan Transformasi Agama-Agama, Satya Wacana University Press.

Vernooij, J.G., 2015, 'Suhadi Cholil "I come from a Pancasila family": A discursive study on Muslim-Christian identity transformation in Indonesian post-Reformasi era', Exchange 44(2), 201-203. https://doi.org/10.1163/1572543X-12341358

Wibowo, A.S., 2018, 'Negara-Pancasila Menurut Driyarkara: Melacak Asal-Usul dan Artinya', in F.W. Setyadi (ed.), Meluhurkan Kemanusiaan: Kumpulan Esai untuk A. Sudiarja, pp. 115-155, Penerbit Buku, Kompas.

Widjaja, P.S., 2020, 'Aktualisasi Pancasila Berdasarkan Etika Kebajikan Kristiani', DUNAMIS: Jurnal Teologi Dan Pendidikan Kristiani 4(2), 143-168. https://doi. org/10.30648/dun.v4i2.247 